\title{
Seed Collection Time Effect on the Germination Rate and Growth of Rubber Tree Rootstock
}

\author{
Junaidi $^{1 *}$ Atminingsih ${ }^{1}$ Mochlisin Andriyanto ${ }^{1}$
}

\author{
${ }^{I}$ Sungei Putih Research Centre, Indonesian Rubber Research Institute \\ *Corresponding author. Email: junaidi.sp5@gmail.com
}

\begin{abstract}
The bud-grafting method is the most economical technique of Hevea brasiliensis propagation. This technique requires rootstock and scion. The high rootstock demand for the replanting program drives the seeds' suppliers to collect assorted seeds from cultivated fields, lead to a high variation in the germination rate. The time from seed dehiscent to seeding was hypothesized to be crucial inflicting an inconsistency in the germination rate and seedling rootstock growth. This present study used rubber seeds of the GT1 clone which were laid under trees' shading to mimic the natural environment. Five laying periods were applied i.e., P0 (directly germinated, control), P1 (laid for one week), P2 (laid for two weeks), P3 (laid for three weeks), and P4 (laid for four weeks). Our study implied that the direct sowing after dehiscent was the best way to attain a high germination rate (GR) $(51.67 \%)$ while delaying seed sowing for one week reduced the GR up to $22.04 \%$. The longer delaying in P2, P3, and P4 did not show significant differences among them which were $13.33 \%, 1.19 \%$, and $4.35 \%$ respectively. However, the seedling showed a similar growth rate including root/shoot ratio regardless of the laying period treatment. The necessity of establishing seed gardens for rootstock was highlighted in which the harvesting of the seeds could be controlled.
\end{abstract}

Keywords: Hevea brasiliensis, bud-grafting, rootstock nursery, planting material

\section{INTRODUCTION}

Para rubber (Hevea brasiliensis) plant material is produced through vegetative propagation. Though some techniques have been studied including stem cutting and tissue culture, grafting is still the most economical technique. This propagation technique requires rootstock and scion. Rootstock will develop to be the root system, while scion will become the aboveground canopy. Thus, for attaining a superior rubber tree, a combination of excellent rootstock and high-yielding scion is essential [1].

The root system is influential for plant growth as it provides anchorage and nutrient acquisition. Indonesia possesses more than three million hectares of rubber trees [2]. Millions of planting materials are demanded in Indonesia solely every year. While breeding programs in $H$. brasiliensis are mainly dedicated to yield upgrade, biotic pathogen tolerance, and abiotic stress adaptation, rootstock improvement is received less attention. Instead of deliberately designed, rootstock recommendations resulted from the cultivated clones' observations such as RRIM 2001, PB 235, and IAN 873 [3]. Rubber seeds for rootstock are ideally produced from a seed garden that consists of recommended clones and received distinctive upkeep practices. However, seeds' suppliers usually collect assorted seeds from common cultivated fields. This practice inflicts a variation in germination rate, seedling growth, and successful grafting percentage.

$H$. brasiliensis seed behaves as recalcitrant which is very sensitive to changes in the environment, has a short life span, no dormancy characterization, and the germination rate rapidly decreased over time [4]. Previous studies had investigated the effort to maintain seed viability and promote germination, yet as it requires additional cost, rubber plantations merely implement the modest technique i.e., submergence in freshwater added by fungicide.

The germination rate is one of the important parameters in the rootstock nursery as it determines the number of seedlings and eventually the number of planting material. Some factors influence the germination rate including seed quality [5], storage [6], and treatment before seeding [7]. However, the studies used rubber seeds collected from the field that might have laid on the ground for a varied time after 
dehisced. The time from seed dehiscent to seeding was hypothesized to be a key factor determining the germination rate and seedling growth.

\section{MATERIALS AND METHODS}

\subsection{Seeds collection and Germination}

The study was carried out at Sungei Putih Research Center, Indonesian Rubber Research Institute, North Sumatra in March - September 2019. The seeds were collected from trees of GT 1 clone. The mature fruits, showed by the dark brownish seed rind, were wrapped by a net pouch (Figure 1). Seeds harvesting was carried in four weeks with a one-week interval. The fully mature fruits, indicated by dry rind were collected and gently cracked.

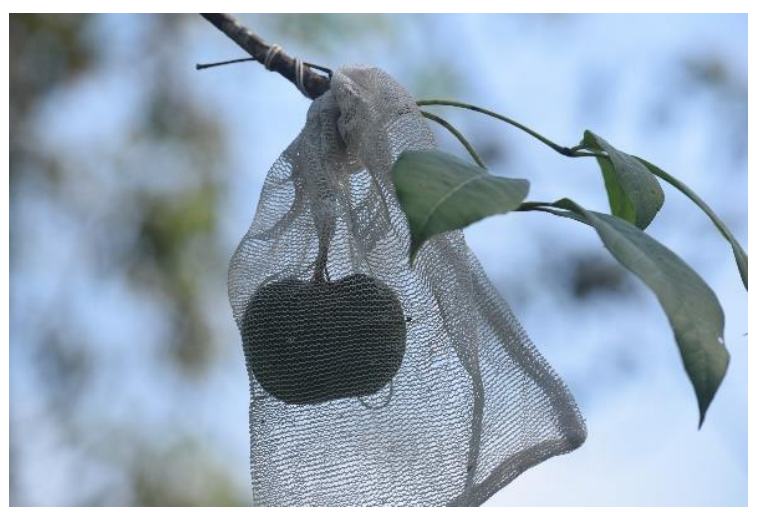

Figure 1. Rubber fruits wrapped by net pouch for seeds harvesting

The selected seeds were submerged in water overnight then were laid under trees' shading to mimic the natural environment. Five laying periods were applied as follows:

P0 : control, directly germinated after submergence

P1 : laid for one week before germination

P2 : laid for two weeks before germination

P3 : laid for three weeks before germination

P4 : laid for four weeks before germination

Twenty-five seeds were used in each treatment with the tree source as replication (three biological replications). The seeds were sowed on the $15 \mathrm{~cm}$ height of sieved sand in a greenhouse and watered daily. The number of germinating seeds was observed weekly for four consecutive weeks. The ratio of germinating seeds $(R G S w)$ was calculated according to the following equation:

$$
R G S w=\frac{N G S w}{N S S} \times 100 \%
$$

NGSw : Number of germinating seeds per week (seeds)

NSS : Total of sowed seeds (seeds)

For germination rate (GR) assessment, the total number of germinating seeds in the first three weeks was used and calculated using an equation as follows:

$$
\begin{aligned}
& \text { GR }=\frac{\text { NGS } 3}{\text { NSS }} \boldsymbol{x} \mathbf{1 0 0 \%} \\
& \text { GR }
\end{aligned} \begin{array}{ll}
: \text { Germination rate }(\%) \\
\text { NGS3 } \quad \begin{array}{l}
\text { Total of germinating seeds in three weeks } \\
\text { (seeds) }
\end{array} \\
\text { NSS } \quad \text { Total of sowed seeds (seeds) }
\end{array}
$$

\subsection{Rootstock Nursery}

Polybags 40 x 50 in size were used for the rootstock nursery which was filled with sieved ultisol topsoil. The polybags were placed outside the greenhouse under direct sunlight and arranged to meet Randomized Complete Block Design (RCBD) where three blocks as the replication. The sprouts were transferred weekly and received standard upkeep including watering (daily), weeding (weekly), and fertilizing (5 g polybag $^{-1}$ N-P-K-Mg: 15-15-6-4 two weeks after transferring).

The seedlings' height was measured from the soil surface to the highest point. The number of leaves observed indicated the total fully formed leaves. The stem diameter was measured $5 \mathrm{~cm}$ above the seedling collar. Seedling height was observed weekly, whilst the number of leaves and stem diameter were observed at the end of the study. Rather than comparing the growth parameters from a different age, the seedling growth rate was calculated by diving growth attributes by the seedling age. The seedling growth parameters assessed included height growth rate (HGR), leaves sprouted rate (LSR), and diameter growth rate (DGR).

\subsection{Biomass Assessment}

At the end of the study, the seedlings were cut at the collar separating aboveground and underground biomass. The belowground biomass was washed with flowing water carefully. All biomass was oven-dried at $70^{\circ} \mathrm{C}$ overnight. The fresh and dry weight were noted accordingly. The root (RAR) and shoot (SAR) accumulation rates were calculated by dividing the dry weight by plant age. The root/shoot ratio (RSR) was calculated according to the following equation:

RGSw : Ratio of germinating seeds per week (\%) 


$$
\begin{array}{ll}
R \boldsymbol{R}= & \frac{\boldsymbol{R D W}}{\boldsymbol{S D W}} \\
\text { RSR } & : \text { Root/shoot ratio } \\
\text { RDW } & : \text { Root dry weight }(\mathrm{g}) \\
\text { SDW } & : \text { Shoot dry weight }(\mathrm{g}
\end{array}
$$

\subsection{Data Analysis}

Statistical analysis was performed using $\mathrm{R}$ Statistic Software version 3.6.1 (R Development Core Team). The analysis of variance (ANOVA) was applied for GR, HGR, LSR, DGR, and RSR parameters. The comparisons were calculated using the Tukey HSD method with $\alpha=0.05$.

\section{RESULT AND DISCUSSION}

\subsection{Germination Rate}

During four weeks of germination, most of the seeds germinated in the first two weeks (Figure 2A). In control treatment (P0), $19.72 \%$ seeds germinated in the first week and $28.89 \%$ seeds in the second week then dropped to only $3.06 \%$ in the third and $1.67 \%$ in the fourth week. The seeds received a oneweek laid period (P1) showed $11.11 \%$ germination in the first week, $12.96 \%$ in the second week then decreased significantly to $5.56 \%$ in the third week, with no seeds germinating after the three weeks. The P2, P3, and P4 exhibited low germination (below 7\% per week) during this study. Our result indicated that the vigorous seeds would germinate in two weeks. The number of germinating seeds declined drastically after two weeks.

Control treatment resulted in the highest germination rate (GR) of $51.67 \%$ while delaying seed collection for one week reduced the GR to $29.63 \%$ (Figure 2B). The GR of P2, P3, and P4 did not show significant differences among them which were $13.33 \%, 1.19 \%$, and $4.35 \%$ respectively. The flowering season varied based on geographical location. The rubber tree produces vigor seeds in its peak season which occurs once a year.

The result supported our hypothesis that the time from seed dehiscent to sowing influences the germination rate. Our study answered the inconsistency issue of the germination rate. As the seeds were collected by the supplier from various fields, they might have been laying for a long time on the field. This effect might be aggravated by the additional storage period. Unlike the orthodox seeds which the GR could be maintained by desiccation treatment, rubber seed is lacking desiccation-tolerant [8]. [9] suggested that carbohydrate and water content were the pivotal parameters maintaining rubber seeds' viability.
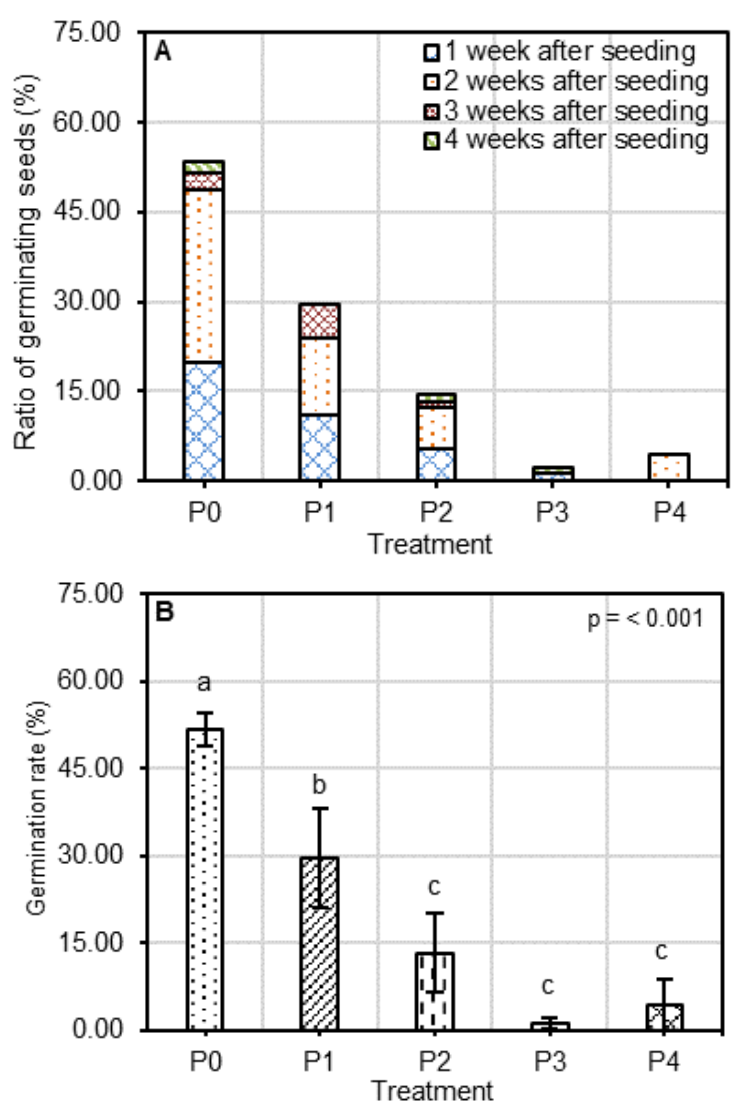

Figure 2. The ratio of germinating seeds (A) and germination rate (B). Error bars indicated standard deviation. Different letters indicated significant differences based on Tukey's HSD comparison with $\alpha$ $=0.05$

The previous study by [4] showed that the temperature of $27^{\circ} \mathrm{C}$ significantly reduced seed GR, while the $18^{\circ} \mathrm{C}$ storage temperature could maintain the seed viability for only 8 weeks. Another study by [10] noted that the chemical compound of PEG 6000 could be used to maintain viability.

\subsection{Seedling Growth}

Figure 3 showed the seedling height until 16 weeks of the rootstock nursery. Although delaying the sowing inflicted a significant decrease on GR, the seeds that managed to germinate showed a similar seedling height to control. The $\mathrm{P} 4$ received four weeks of sowing delay, the longest laying period in this experiment, exhibited higher seedling height at the early stage suggesting that the survivals were excellent seeds. The control treatment showed a similar height to $\mathrm{P} 1, \mathrm{P} 2$, and $\mathrm{P} 3$ at the early stage then increased significantly after 10 weeks. 


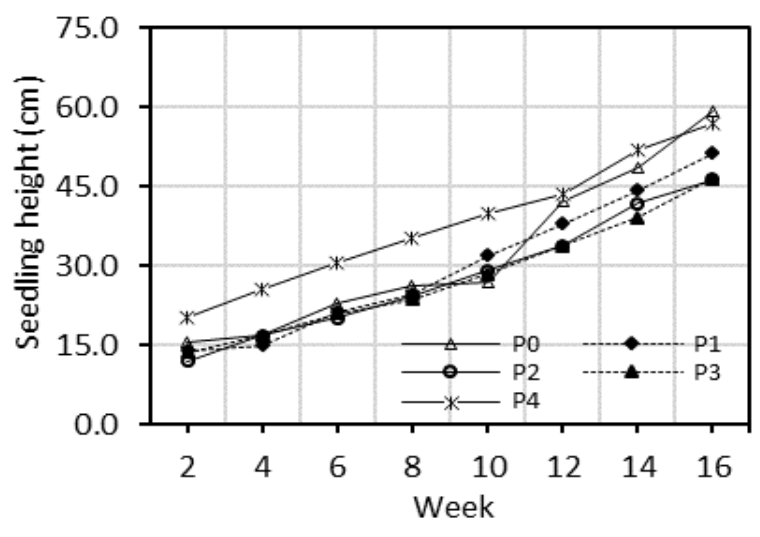

Figure 3. Seedling height in 16 weeks' observation

In this study, we calculated the growth rate including height growth rate (HGR), leaves sprouted rate (LSR), and diameter growth rate (DGR) (Table 1). Our data indicated that the growth rate of the seedling was not significantly different among treatments, suggesting that the seedling could be used for rootstock regardless of the source of the seeds. The only issue was economic constraint due to a low germination rate. Our result was in contrast with [5] which suggested that seedling from high GR resulted in higher seedling growth than lower GR.

Besides the common upkeep practices, some agronomical modifications could be performed to increase rubber seedlings' growth such as the application of wood biochar and arbuscular mycorrhiza infestation [11]. The stem diameter is the most important parameter as in the grafting propagation technique, the scion will be attached to the rootstock stem. Based on the age of the rootstock, grafting technique in Hevea propagation could be distinguished to brown grafting using 7-12 months of rootstock, green grafting using (4-7 months), and early grafting (2-3 months) [12].

Table 1. Seedlings' growth rate parameters of each treatment. + indicated standard deviation

\begin{tabular}{cccc}
\hline Treatment & $\begin{array}{c}\text { HGR } \\
(\mathbf{c m} \\
\left.\text { week }^{-1}\right)\end{array}$ & $\begin{array}{c}\text { LSR } \\
(\text { leaves } \\
\left.\text { week }^{-1}\right)\end{array}$ & $\begin{array}{c}\text { DGR } \\
(\mathbf{m m} \\
\left.\text { week }^{-1}\right)\end{array}$ \\
\hline P0 & $4.37 \pm 1.15$ & $0.81 \pm 0.13$ & $0.45 \pm 0.04$ \\
P1 & $3.66 \pm 0.40$ & $0.80 \pm 0.21$ & $0.46 \pm 0.08$ \\
P2 & $3.74 \pm 0.42$ & $0.65 \pm 0.08$ & $0.38 \pm 0.02$ \\
P3 & $3.30 \pm 0.43$ & $0.67 \pm 0.09$ & $0.37 \pm 0.03$ \\
P4 & $3.56 \pm 1.29$ & $1.69 \pm 0.27$ & $0.40 \pm 0.08$ \\
\hline & $\mathrm{p}=0.7773$ & $\mathrm{p}=0.1964$ & $\mathrm{p}=0.5450$
\end{tabular}

HGR $=$ height growth rate, $\mathrm{LSR}=$ leaves sprouted rate, $\mathrm{DGR}=$ diameter growth rate

\subsection{Biomass Accumulation}

Several studies showed that the combination of rootstocks and scion determined the incompatibility, growth, and yield [13,14]. A study by [15] suggested that the rootstock and scion interaction did not influence rubber yield significantly, implied that the assorted seeds were acceptable for rootstock seedlings. The root accumulation rate (RAR) and shoot accumulation rate (SAR) of the samples indicated that the biomass accumulation rate was not significantly different among treatments (Table 2). Furthermore, the root/shoot ratio exhibited a similar value (0.40-0.49), implied that the belowground and aboveground biomass accumulation underwent the same pattern regardless of the quality of the seed.

Our result partially supported our hypothesis that seed collection is crucial for attaining a high germination rate. Nonetheless, after the seed germinated and transplanted to the rootstock nursery, the growth of the seedling showed a similar rate regardless of the laying period treatment. It highlighted the necessity to establish seed gardens for rootstock which the harvesting of the seeds could be controlled.

Table 2. Seedlings' biomass accumulation rate of each treatment. \pm indicated standard deviation.

\begin{tabular}{cccc}
\hline \multirow{2}{*}{ Treatment } & RAR & SAR & Root/shoot \\
\cline { 2 - 3 } & $\ldots \ldots \ldots . .\left(\right.$ g week $\left.^{-1}\right) \ldots \ldots .$. & ratio \\
\hline P0 & $0.65 \pm 0.16$ & $1.40 \pm 0.28$ & $0.46 \pm 0.06$ \\
P1 & $0.63 \pm 0.24$ & $1.63 \pm 0.59$ & $0.40 \pm 0.14$ \\
P2 & $0.35 \pm 0.16$ & $0.90 \pm 0.49$ & $0.48 \pm 0.28$ \\
P3 & $0.17 \pm 0.03$ & $0.36 \pm 0.04$ & $0.49 \pm 0.13$ \\
P4 & $0.87 \pm 0.54$ & $1.73 \pm 0.32$ & $0.48 \pm 0.20$ \\
\hline & $\mathrm{p}=0.1200$ & $\mathrm{p}=0.4784$ & $\mathrm{p}=0.5200$ \\
\hline
\end{tabular}

$\mathrm{RAR}=$ The root accumulation rate, $\mathrm{SAR}=$ shoot accumulation rate (SAR)

\section{CONCLUSION}

Our observation indicated that rubber most rubber seeds would germinate in two weeks, after that the number of germinating seeds would decline drastically. The time from seed dehiscent to the sowing influenced the germination rate. Direct sowing was the best way to obtain a high germination rate while delaying seeds' sowing would reduce it drastically. However, after transplanted to rootstock nursery, the seedlings exhibited a similar growth rate regardless of the laying period on the field. 


\section{REFERENCES}

[1] N. Khotcharat, S. Sdoodee, U. Meesawat, Growth performance of clonal rubber rootstocks and combining ability test with the scion of clone RRIM 600, Agriculture and Natural Resources 50(2) (2016) 98-103. DOI: http://dx.doi.org/10.1016/j.anres.2015.07.003

[2] Direktorat Jenderal Perkebunan, Statistik Perkebunan Indonesia 2016-2018: Karet. Direktorat Jenderal Perkebunan, Kementerian Pertanian Republik Indonesia, 2018. [In Bahasa Indonesia]

[3] N.W. Daud, S.J. Mokhatar, C.F. Ishak, Assessment of selected Hevea brasiliensis (RRIM 2000 Series) seeds for rootstocks production, African Journal of Agricultural Research 7(21) (2012) 3209-3216. DOI: http://dx.doi.org/10.5897/AJAR12.272

[4] N.H. Shuib, A.I. Ismail, A. Adinan, S.M.H.S. Abd Hadi, Study on biochemical properties of Hevea brasiliensis seeds stored at three different temperatures, Research Journal of Seed Science 11(1) (2018) 1-11. DOI: http://dx.doi.org/10.3923/rjss.2018.1.11

[5] V. Wongvarodom, W. Duang-iat, W. Santipracha, S. Sdoodee, Effect of seed quality on field emergence and seedling performance of rubber (Hevea brasiliensis), Kasetsart JournalNatural Science 48 (2014) 376-382.

[6] Nurhayati, N. Basuki, Ainurrasjid, Pengaruh lama dan media penyimpanan benih terhadap perkecambahan karet (Hevea brasiliensis Muell Arg) klon PB 260, Jurnal Produksi Tanaman 3(7) (2015) 607-614. [In Bahasa Indonesia]

[7] N.M.C. Nayanakantha, K.D. Madhushani, L.A.R. Amarathunga, G.A.S. Wijesekera, P.D. Pathirana, W. Karunatilaka, D.L.N. de Zoysa, M.N. de Alwis, R. Handapangoda, P. Seneviratne, Treatment with nitric oxide and seed coat removal improve germination and growth of rubber (Hevea brasiliensis), Journal of the Rubber Research Institute of Sri Lanka 96 (2016) 33-49. DOI: http://doi.org/10.4038/jrrisl.v96i0.1840

[8] P. Berjak, N.W. Pammenter, Implications of the lack of desiccation tolerance in recalcitrant seeds, Frontier in Plant Science 4(478) (2013) $1-9$.

DOI: http://doi.org/10.3389/fpls.2013.00478

[9] R. Hartawan, Y. Nengsih, Kadar air dan karbohidrat berperan penting dalam mempertahankan kualitas benih karet,
Agrovigor 5(1) (2012) 103-112. [In Bahasa Indonesia]

[10] Charloq, A. Yazid, P.P. Gustiansya, Viability of shelled rubber (Hevea brasiliensis Muell. Arg.) seed treated with PEG 6000 at different drying times in storage period, Journal of Agronomy 16(2) (2017) 83-86. DOI: http://doi.org/10.3923/ja.2017.83.86

[11] R.S. Dharmakeerthi, J.A.S. Chandrasiri, V.U. Edirimanne, Effect of rubber wood biochar on nutrition and growth of nursery plants of Hevea brasiliensis established in an Ultisol, Springer Plus 1(1) (2012) 1(84) 1-12. DOI: http://doi.org/10.1186/2193-1801-1-84

[12] Junaidi, Atminingsih, N. Siagian, Pengaruh jenis mata entres dan klon terhadap keberhasilan okulasi dan pertumbuhan tunas pada okulasi hijau di polibeg, Jurnal Penelitian Karet 32(1) (2014) 21-30. [In Bahasa Indonesia]

[13] J.A. Darikova, Y.V. Savva, E.A. Vaganov, A.M. Grachev, G.V. Kuznetsova, Grafts of woody plants and the problem of incompatibility between scion and rootstock (a review), Journal of Siberian Federal University Biology 1 4(1) (2011) 54-63.

[14] K. Yuan, X. Ding, L.F. Yang, Z.H. Wang, W.F. Lin, J.H. Cao, Proteome analysis of interaction between rootstocks and scions in Hevea brasiliensis, African Journal of Biotechnology 10(66) (2011) 14816-14825. DOI: http://doi.org/10.5897/AJB11.1844

[15] T. Gireesh, Y.A. Varghese, K.E. Woeste, V.C. Mercykutty, J.G. Marattukalam, Effect of monoclonal and assorted seedling rootstocks on long term growth and yield of Hevea clones, Silvae Genetica 61(1-2) (2012) 52-27. DOI: http://doi.org/10.1515/sg-2012-0007 